\title{
Injury Indicator of Glyphosate to Alfalfa as affected by Recurrent Selection
}

\author{
M. Abd El- Sattar Ahmed, ${ }^{1 *}$ Ahlam, H. Mostafa, ${ }^{2}$ Thanaa. I. Milad, ${ }^{1}$ and T.A. Mahmoud ${ }^{2}$ \\ ${ }^{1}$ Crop Science Dept. Fac. Agric., Alexandria University. \\ ${ }^{2}$ Forage Res. section, Agric. Res. Center, Nubaria, Egypt. \\ * Corresponding author.
}

\begin{abstract}
In Egypt, alfalfa represts a suitable choice for forage cultivation expansion, since, the available land and water are of lower quality. The early seeding stage of alfalfa is the most val near able to weed competition. Research results regarding improvement of alfalfa tolerance to glyphosate in Egypt is relatively scare. The recent study was an attempt to trace variability in glyphosate tolerance of alfalfa germplasm. The improvement in tolerance due to recurrent selection was also considered. Alfalfa plant materials (Medicago sativa,L. ) used in that recent study were five base populations . Two cycles of recurrent selection for Glyphosate tolerance were imposed on each base population. Evaluation of selected cycles $\left(\mathrm{C}_{1}\right.$ and $\mathrm{C}_{2}$ ) along with base populations $\left(\mathrm{C}_{0}\right)$ was carried-out for each population as a split plot design with Glyphosate treatment (+ and -) as main plots and populations $\left(\mathrm{C}_{0}, \mathrm{C}_{1}\right.$ and $\left.\mathrm{C}_{2}\right)$ as a sub -plots. Glyphosate treated plots were evaluated for injury characters, i.e.; total chlorophyll, injury level, percent of death and shikimic acid content.

Significant ( $\mathrm{p} \geq 0.01$ ) variations were detected among the studied alfalfa population. Also, the recorded values for all injury indicator characters significantly varied among selection cycles. In the meantime, the interactions between the studied population and selection cycles were significant $(\mathrm{p} \geq 0.05)$. Chlorophyll content expressed as "spade" units was not changed after one cycle of selection (30.22 and 29.15 spade for base population $\left(\mathrm{C}_{0}\right)$ and first cycle of selection $\left(\mathrm{C}_{1}\right)$ as an average over the studied population, respectively). While, the second cycle of selection resulted in significantly higher level of total chlorophyll content (34.51 spade). This might indicates that tolerance to glyphosate was associated to higher chlorophyll content. The value of injury level decreased in both of Siwa and Hasawi populations after the first cycle of selection to glyphosate tolerance(-19.51 and $-13.22 \%$, respectively). Meanwhile, the progress of selection for glyphosate tolerance in alfalfa populations, gave a substantial decrease in value of injury level in all studied populations, except for, Siwa population that recorded an increase in value of injury level $(-47.05,-44.44,-40.91$ and -4.35 percent of the respective value recorded for injury level at the first cycle of selection in C.U.F101, Baladi 1, Sirivar and Hasawi populations, respectively).Change in shikimic acid content represented by a decrease reached $-35.05,-22.99,-5.49$ and $4.26 \%$ in Siwa, Baldi 1, C.U.F 101 and Sirivar populations, respectively, after the first cycle of selection for glyphosate tolerance.

Only Hasawi population recorded an increase in shikimic acid content reached $+251.8 \%$ relative to base population. While, after the second cycle of selection an increase in shikimic acid content reached +63.60 and $+4.688 \%$ for C.U.F101 and Baldi1 populations relative to $\left(\mathrm{C}_{1}\right)$. Sharing genes among tolerant individuals, increase the frequency of genes responsible for tolerance, consequently expressing higher levels of cide- tolerance. The recent results assume the possibility of obtaining glyphosate tolerant alfalfa population depending on frequent cycles of recurrent selection.
\end{abstract}

Keywords: Alfalfa, Injury indicators, Glyphosate, Shikamic acid.

\section{INTRODUCTION}

Alfalfa "Medicago sativa, L." that has large genetic diversity, is among the most important forage crops "king of forages". That provided alfalfa genotypes to occupy different environments. The importance of alfalfa forage goes to its high content of protein and minerals, beside, high degree of palatability. Voulianteer weeds in alfalfa fields are mostly of lower quality and palatability, especially "Urospermumpicriods" and "Xanthium spinosus". That affect the value and persistence of alfalfa fields.

In Egypt, the total area cultivated to alfalfa was about 79 thousand faddan (one faddan $=4200 \mathrm{~m}^{2}$ ). The great shortage in animal protein force the expansion of forage cultivation. Alfalfa represts a suitable choice, since, the available land and water are of lower quality.
The early seedling stage of alfalfa is the most vulnerable to weed competition. Weed hazards extend up to the third cutting of the establishment year. Selective herbicides as a control measure in alfalfa fields were used very little. That goes to its high price, limited effectiveness and herbicidal injury. Glyphosate is a systemic non-selective foliarly applied herbicide. Irrespective of glyphosate non- selectivity, several plant species exhibit levels of tolerance to its effect (Gottrup, et.al, 1976), reductions to sorption and limited translocation from vegetative to reproductive organs (Neal et. al, 1985). Several trials has been made to select a glyphosate tolerance genotypes in vitro. In each of them tolerance was due to an increase in 5enolpyruvy shikimate 3-phosphate synthase (EPS PS) activity (Shah et.al, 1986). 
Shikimic acid (SHA) pathway includes the production of flavonoids, lignins, indole derivatives and many aromatic alkaloids, which are a key components in plant denfense. High pressure liquid chromatography (HPLC) allowed for quantitative determination of SHA. Glyphosate transform shikimic acid to chorismate, consequently, inhibites the synthesis of aromatic compounds produced through the shikimate and chorismate pathway (Amrhein et. al, 1980). Variations in tolerance to glyphosate traced in soybean (Glycine max, L. Merr.) (Duncan and weller, 1987). Developing herbicide-tolerant crops through traditional plant breeding reached reasonable success. In canola, commercial cultivars were developed by backcrossing a cytoplasmic triazine resistant genotype to birdspape mustard (B.comoestris, L.) (Beversdorf and Koh, 1987). Selection for herbicide resistance in cross pollinated lolium population gave rapid response relative to that achieved in a self-pollinated Avena population (Owen et.al, 2007). An improvement in birds foot trefoil tolerance to 2,4- D was achieved after five cycles of recurrent selection. The levels of tolerance to the herbicide, reached five folds that of unselected individuals (Devine et.al, 1975). Hartwig, 1987, indicated that, genotype by environment effect abandoned the efforts to increase tolerance of soybean germplasm to glyphosate, although genetic variation excisted.

Research results regarding improvement of alfalfa tolerance to glyphosate in Egypt is relatively scare. The recent study was an attempt to trace variability in glyphosate tolerance of alfalfa germplasm. The improvement in tolerance due to recurrent selection was also considered.

\section{MATERIALS AND METHODS}

Alfalfa plant materials (Medicago sativa, L.) used in that recent study will be referred to as the five base populations. Two cycles of recurrent selection for Glyphosate tolerance were imposed on each base population. Each cycle of selection within a base germplasmis hereafter referred to as a population. C.U.F 101 population Pedigree was (University of California Davis, UC 76, 1972, released by). C.U.F seed company siriver population (Hunter river x C.U.F 101 and UC 110 and UC 112 released by). Hasawi population is a land Land race naturally originated on Saudi Arabia. Baldi population Selected from EL-Wadi EL-Gedid landrace by Forage Research Department of ARC, Egypt. Siwa population is a land race naturally originated on Siwa Oasis of west-desert, Egypt.

Cycle one was practiced on 2800 plants per each base population $\left(\mathrm{C}_{0}\right)$. Base populations were seeded at density of 100 plant. $\mathrm{m}^{-2}$ (considering seed index and germination percentages). Each germplasm seeded in $28 \mathrm{~m}^{2}$ (20 rows of $1.75 \mathrm{~m}$ long and $0.80 \mathrm{~m}$ apart) on Nubaria Agricultural Research Station, North of Egypt. Seeding date was, May $27^{\text {th }}, 2015$. Four weeks after seeding, plants $(8-15 \mathrm{~cm}$ tall) were treated with $0.56 \mathrm{~kg}$ acid equivalent per hectar $\left(\right.$ ae.ha $^{-1}$ ) of Glyphosate (Round up ${ }^{\circledR}$ ) diluted in 480 liter of water (L). Survived plants were left to complete the first cutting growth (two months). Regrowth of the second cutting at $20-25 \mathrm{~cm}$ height was sprayed by $0.84 \mathrm{~kg}$ ae. $\mathrm{ha}^{-1}$ glyphosate in $480 \mathrm{~L}$ water. ha ${ }^{-1} .14$ day after treatment, plants was rated for injury on a 1 to 4 scale (where $1=$ uninjured, $2=$ injured shoot, $3=$ dead shoot with live auxiliary shoots and $4=$ dead seeding)(Boerboomet.al.1991). The uninjured plants were selected uprooted and transplanted to an isolated plots surrounded and covered by insect proof cloth for flowering and seed setting .Plants selected for Glyphosate tolerance from each germplasm were 100 plant .Each germplasm was caged separately in cloth house and a portable honey bees heave (Apis mellifera, L.) was used as pollinators (for random matting among plants). Seeds were harvested for each separate plant as a half-sib family on June, $15^{\text {th }}, 2016$. Equale seed weight from each selected half-sib family seeds were bulked to from first improved cycle $\left(\mathrm{C}_{1}\right)$. The second cycle of selection was practiced for each separate improved population. Each population was seeded in 20 rows of $1.25 \mathrm{~m}$. long and $0.80 \mathrm{~m}$ apart (2000 plant). Four week old seedlings were treated with Glyphosate at $0.56 \mathrm{~kg}$ ae. $\mathrm{ha}^{-1}$ in 480 liters of water. Fourteen days after treatment, injury levels were rated as $1=$ uninjured, $2=$ injured shoot, $3=$ dead shoot with live auxiliary shoots and $4=$ dead seeding. The uninjured plants were selected uprooted and transplanted to an isolated plots surrounded and covered by insect proof cloth for flowering and seed setting .Plants selected for Glyphosate tolerance from each germplasm were 100 plant .Each germplasm was caged separately in cloth house and a portable honey bees heave (Apis mellifera L.) was used as pollinators (for random matting among plants). Seeds were harvested for each separate plant as a half-sib family on June, $15^{\text {th }}$,2017.Equale seed weight from each selected half-sib family seeds were bulked to from second improved cycle $\left(\mathrm{C}_{2}\right)$.

Evaluation of selected cycles $\left(\mathrm{C}_{1}\right.$ and $\left.\mathrm{C}_{2}\right)$ along with base populations $\left(\mathrm{C}_{0}\right)$ was carried out for each population as a split plot design with Glyphosate treatment $(+$ and -$)$ as main plots and populations $\left(\mathrm{C}_{0}, \mathrm{C}_{1}\right.$ and $\left.\mathrm{C}_{2}\right)$ as a sub -plot. Four replicates were used. Plot size was three rows of $1.80 \mathrm{~m}$ long and $0.15 \mathrm{~m}$ apart. Planting of seeds took place at November $1^{\text {st }}$, 2017. Glyphosate treatment was applied 30 days after planting at $0.84 \mathrm{~kg}$ ae. $\mathrm{ha}^{-1}$ in 480 liter of water. Fourteen days after treatment, injury levels were rated as $1=$ uninjured, $2=$ injured shoot, $3=$ dead shoot with live auxiliary shoots and $4=$ dead seedling. Glyphosate treated plots were 
evaluated for the following injury characters; I) total chlorophyll; a sample of mature leaves collected from the current shoots were used to determine leaf chlorophyll content (SPAD units) as average of three reading per plot (SPAD-502 Plus, Konicamonlta. com, Markwell et al. 1995), II) injury level: a scale of 1 to 4 was used (average of five reading per plot), III) percent of death: recorded as an average of five samples each of ten plants, Tv) shikimic acid: dry and wet tissue samples from treated alfalfa plants were grounded in a liquid nitrogen with a mortar and pestle, and Shikimic acid was extracted by the following methods: $200 \mathrm{mg}$ of plant tissue was ground in two $\mathrm{mL}$ of $0.25 \mathrm{~N} \mathrm{HCL}$ for five minutes and then sonicated for one minutes (w-380 Neat systems-UL Transonic, Inc, ultra sonic processor USA). Plant cell components were then separated by centrifugation at $15000 \mathrm{~g}$ for $30 \mathrm{~min}$. Alfalfa extracts $(10-25 \mu \mathrm{L})$ were filtered through a $0.22 \mu \mathrm{m}$ nylon membrane and were analyzed by HPLC (Instrument Agilent Technology infinity 1260. Colum: ZORBAX SB-C ${ }_{18} 4.6 X 250 \mathrm{~mm}$ particles diameters $5 \mu \mathrm{m})$. Samples were standard by a $\geq 98 \%$ pureBiochemic $\mathrm{C}_{7} \mathrm{H}_{10} \mathrm{O}_{5}$, (Carl ROTH GmbH. co. www. cart ROTH.Com.).Results were expressed as $\mu \mathrm{mol}$ per $\mathrm{g}^{-1}$ of tissue (Zelaya et. al. 2011). Calibration Curves (Figure 1); shikimic acid at exp. RT: 3.817 MWD1 A, Sig=215, 4 Ref=off Correlation: 0.99998 Residual Std. Dev.: 2.37342 Formula: $\mathrm{y}=\mathrm{mx}+\mathrm{b} \mathrm{m}: 5785.08526 \mathrm{~b}:-1.27194 \mathrm{e}-1$ $\mathrm{x}$ : Amount y: Area. Ret Time Sig was 3.817[min]. Figure 2; represented HPLC curves of area and time of shikimic acid in the sample.

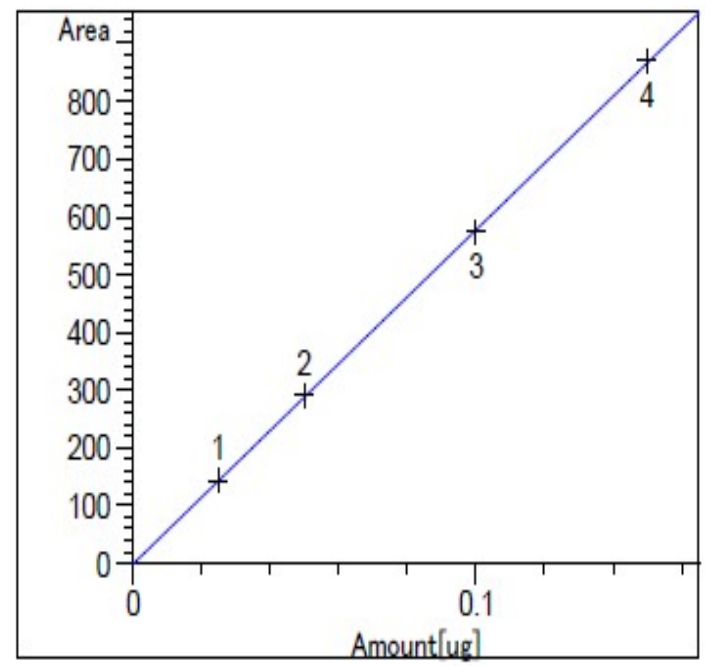

Fig. 1: standard Calibration Curvesof shikimic acid.

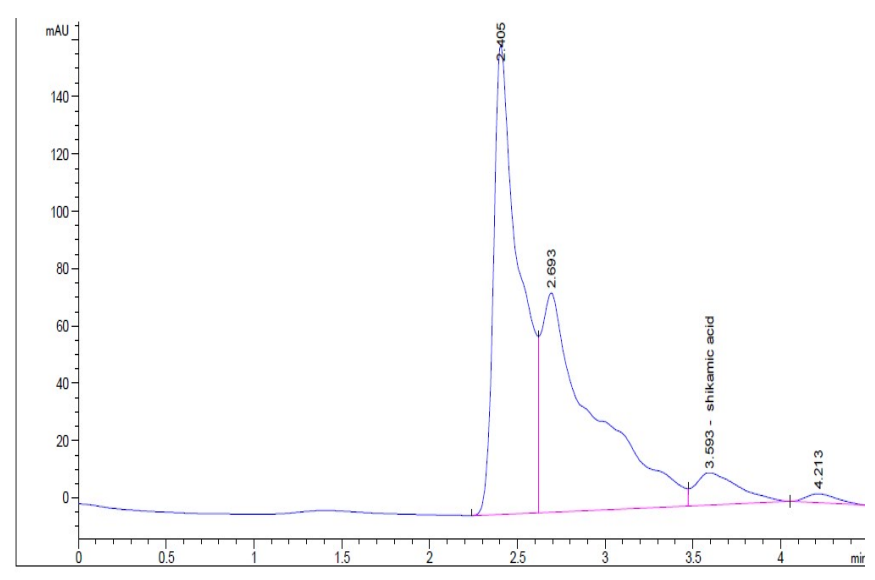

Fig. 2: HPLC curves of shikimic acid in the sample. 


\section{RESULTS AND DISCUSSION}

\section{Response to selection:}

Glyphosate treated plots were evaluated for injury characters, i.e.; total chlorophyll, injury level, percent of death and shikimic acid content. Mean squares of cide injury indicators (total chlorophyll, injury level, percent of death and shikimic acid content) were presented in Table (1). Significant $(p \geq 0.01)$ variations were detected among the studied alfalfa population. Also, the recorded values for all injury indicator characters significantly varied among selection cycles. In the meantime, the interactions between the studied population and selection cycles were significant $(\mathrm{p} \geq 0.05)$. This might indicate variable response of population to progress of selection in term of direction or magnitude of response.

Table (2), presented mean values of cide injury indictators (total chlorophyll, injury level, percent of death and shikimic acid content) for alfalfa populations and selection cycles. As for, total chlorophyll content(spade), the studied populations showed significantly similar chlorophyll content, except for, Baladil that expressed significantly lower value $(34.78,31.87,31.22,31.02$ and 27.57 (spade)for each of Siwa, C.U.F 101, Sirivar, Hasawi and Baladilpopulations, respectively). Chlorophyll content expressed as "spade" units was not changed after one cycle of selection (30.22 and 29.15 spade for base population $\left(\mathrm{C}_{0}\right)$ and first cycle of selection $\left(\mathrm{C}_{1}\right)$ as an average over the studied population, respectively). While, the second cycle of selection resulted in significantly higher level of total chlorophyll content (34.51 spade). This might indicates that tolerance to glyphosate was associated to higher chlorophyll content.

Over selection cycles, the least percentage of death associated with glyphosate treatment were scored by Siriver germplasm $(39.79 \%)$ and C.U.F. 101 (45.87). This might due to the genetic relationship between the two germplasms. Baladi 1 and Siwa germplasms gave relatively high percent of death over selection cycles, since, it had not subjected to any glyphosate pressure (68.33 and $68.13 \%$, respectively). Also, it was noticeable that, the tolerance to glyphosate indicated by lower death percentage was associated with the progress of selection (65.27, 53.50 and $52.87 \%$ for base population, cycle one and cycle two, respectively). Injury level rate, was significantly least scored by Siriver germplasm over selection cycles (2.167). Meanwhile, cycle two of selection significantly indicated the least injury level. Shikimic acid was significantly least presented in Siriver germplasm over selection cycles $(39.91 \mu \mathrm{g} / \mathrm{g})$. While, selection cycles gave insignificantly variable Shikimic acid content.

Table 1: Mean squares of cide injury indicators (total chlorophyll, percent of death, Square injury level and Shikimic acid) for Glyphosate treated populations.

\begin{tabular}{lcccccc}
\hline S.O.V & d.f. & \multicolumn{3}{c}{ M.S } & \multicolumn{2}{c}{ Shikimic acid } \\
\cline { 3 - 7 } & & $\begin{array}{c}\text { Total } \\
\text { chlorophyll }\end{array}$ & $\begin{array}{c}\text { percent } \\
\text { of death }\end{array}$ & $\begin{array}{c}\text { Square } \\
\text { Injury level }\end{array}$ & d.f. & M.S \\
\hline Rep & 3 & $37.082^{\text {N.S }}$ & $0.039^{*}$ & $0.084^{*}$ & 1 & $8.610^{\text {N.S }}$ \\
Population (P) & 4 & $79.072^{* *}$ & $0.150^{* *}$ & $0.109^{* *}$ & 4 & $823.9^{* *}$ \\
Selection cycles (S) & 2 & $160.547^{* *}$ & $0.051^{*}$ & $0.234^{* *}$ & 2 & $35.00^{\text {N.S }}$ \\
PXS & 8 & $67.631^{* *}$ & $0.111^{* *}$ & $0.106^{* *}$ & 8 & $951.5^{* *}$ \\
error & 42 & 20.297 & 0.011 & 0.026 & 14 & 61.85 \\
\hline
\end{tabular}

*,** significant at 0.05 and 0.01 levels of probability respectively.

N.S.; not significant different

Table 2: Mean of cide injury indicators (total chlorophyll, percent of death, injury level and Shikimic acid) for glyphosate treated plots of studied alfalfa populations and cycles of selection.

\begin{tabular}{lccccc}
\hline \multicolumn{1}{c}{ Factors } & $\begin{array}{c}\text { Level of } \\
\text { factor }\end{array}$ & $\begin{array}{c}\text { Total chlorophyll } \\
\text { contend(spade) }\end{array}$ & $\begin{array}{c}\text { percent of } \\
\text { death }\end{array}$ & Injury level & $\begin{array}{c}\text { Shikimic acid } \\
\mu \mathrm{g} / \mathrm{g} \text { F.W. }\end{array}$ \\
\hline \multirow{3}{*}{ Population } & C.U.F 101 & 31.87 & 45.87 & 2.479 & 46.14 \\
& Hasawi & 31.01 & 63.95 & 2.979 & 60.75 \\
\cline { 2 - 6 } & Sirivar & 31.22 & 39.79 & 2.167 & 38.91 \\
\cline { 2 - 6 } & Baladi 1 & 27.57 & 68.33 & 2.583 & 64.94 \\
\hline L.S.D & Siwa & 34.78 & 68.13 & 2.500 & 41.42 \\
\hline \multirow{2}{*}{ Selection } & & 3.317 & 0.086 & 0.133 & 9.739 \\
cycles & $\mathrm{C}_{0}$ & 30.22 & 65.27 & 2.613 & 49.68 \\
\hline L.S.D & $\mathrm{C}_{1}$ & 29.15 & 53.50 & 2.850 & 52.58 \\
\hline N.S.; & $\mathrm{C}_{2}$ & 34.51 & 52.87 & 2.163 & 49.15 \\
\hline
\end{tabular}

N.S.; not significant different 
Table (3), represented the effect of the interaction between alfalfa populations and selection cycles in alfalfa total chlorophyll content. In both of Siriver and Siwa populations, chlorophyll content decreased by 32.61 and 2.208 percent with the first cycle of selection to glyphosate tolerance, whereas, in the rest of studied population, had an increased chlorophyll content by $12.57,5.727$ and 3.108 percent, for C.U.F 101, Hasawi and Baladi 1 populations, respectively. The difference in direction of chlorophyll content response and the difference in magnitude of content, might explain the reasons for significant interaction between population and selection cycle. Meanwhile, the progress ofselection for glyphosate tolerance in alfalfa populations, gave a substantial increase in total chlorophyll content, except for, C.U.F 101 populations, that presented an inverted trend.The magnitude of increase in total chlorophyll content reached $30.59,75.61,5.356$ and 4.183 percent of the respective value recorded for the first cycle of selection in Hasawi, Siriver, Baladi 1 and Siwa populations, respectively. These results match true with the findings recorded by Zobiole etal, 2011, whose showed that, glyphosate significantly decreased chlorophyll content compared with the non-glyphosate treated control. The reduction was more pronounced as the glyphosate rate increased and application time delayed. These findings are consistent with reports by farmers that some glyphosate-resistant soybean varieties are visually injured by glyphosate. Duke et. al 2003, found that, glyphosate-resistant soybean showed chlorophyll content of both first resistant generation (RR1) and second resistant generation (RR2) of decreased photosynthetic rates as a result of direct damage of glyphosate to chlorophyll. Reddy and Zablotowicz, 2003, studied glyphosate-resistant soybean response to various salts of glyphosate and glyphosate accumulation in soybean nodules. They found that, glyphosate can physiologically immobilize these nutrients in the tissues and compromise chlorophyll production. Although the visual injuries are likely to happen in first resistant generation (RR1), soybeans after glyphosate application are usually considered to be non-persistent as the yellow flashing tends to disappear within the first two weeks after herbicide application. On the other hand, Muooz-Rueda et.al 1986, studied the effects of glyphosate [Nphosphonomethyl) glycine] on photosynthetic pigments, stomata response and photosynthetic electron transport in Medicago sativa and Trifolium pratense. They reported that, decreased chlorophyll can be caused by carotenoid loss induced by sublethal doses of glyphosate.

The effect of the interaction between alfalfa populations and selection cycles on percent of death (Table 3).Showed that, C.U.F101, Siwa and Hasawi populations recorded a decrease in percentage of death reached $-52.22,-42.96$ and $-25.74 \%$, respectively, after one cycle of selection to glyphosate tolerance. While, Baladi 1 and Sirivar populations recorded an increase in percentage of death reached +51.85 and +45.65 , respectively, as a result of one cycle of selection to glyphosate tolerance. The different in direction of response of death percentage and the difference in magnitude of figures, might explain the reason for significant interaction between population and selection cycles. Mean while, the progress of selection for glyphosate tolerance in alfalfa populations $\left(\mathrm{C}_{2}\right)$, gavean increase in percentage of death in all populations, except for, Hasawi and C.U.F101 populations (-30.69 and $-16.07 \%$, respectively). These two populations expressed similar response after one cycle of selection. These results might support the findings recorded by Antonovics and Bradshaw 1970 and Antonovics, 1971, whose found that, the greater the kill rate of a cide, the more rapidly the enrichment for resistant strains, unless $100 \%$ kill is achieved. They practiced selection of ecotypes representing various species that are resistant to much higher levels of copper, zinc and lead. In pastures, such tolerant ecotypes represent the source of revegetation after kill of sensitive and normal ecotypes by abnormal levels of cides. The frequency of tolerant ecotypes in normal population is low, consequently, revegetation by resistant ecotypes requires few seasons. They also noticed that the frequency of tolerant ecotypes vary among populations belongs to one species. Zenk, 1974, showed that, selection pressure that we use in programs, mostly result in killing percentage less than $90-95 \%$. The remaining plant in the field are "escapees". He added that, increasing the dose of cide through frequent application in subsequent cycles of selection, hardly increases kill of susceptible ecotypes but may be lethal to a limited percentage of resistant plants among the escapees. These results might illustrate the obtained results in death percentage. Busi and Powles, 2011, noticed that, selection of glyphosate tolerant Lolium rigidum was associated with concomitant reduction in sensevity to another completely different herbicide (paraquate). Sensitivity to "paraquate" was reduced as a consequence of recurrent selection for low doses of glyphosate. Their results showed that, the lethal dose of paraquate that can cause $50 \%$ mortility of plants reached four times the respective dose that can cause the same percentage of mortility in unselected susceptible plants.

The interaction between alfalfa populations and selection cycles reflected on values of injury level presented in Table 3 and fig (3). 


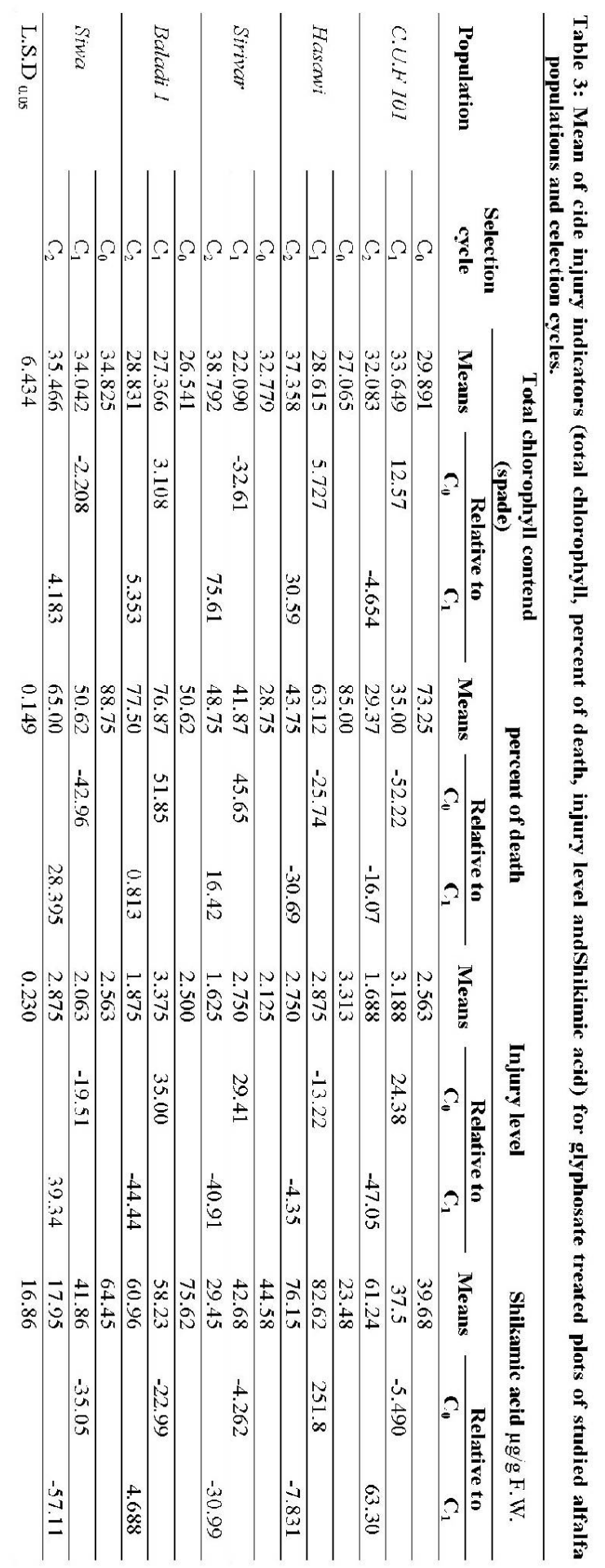




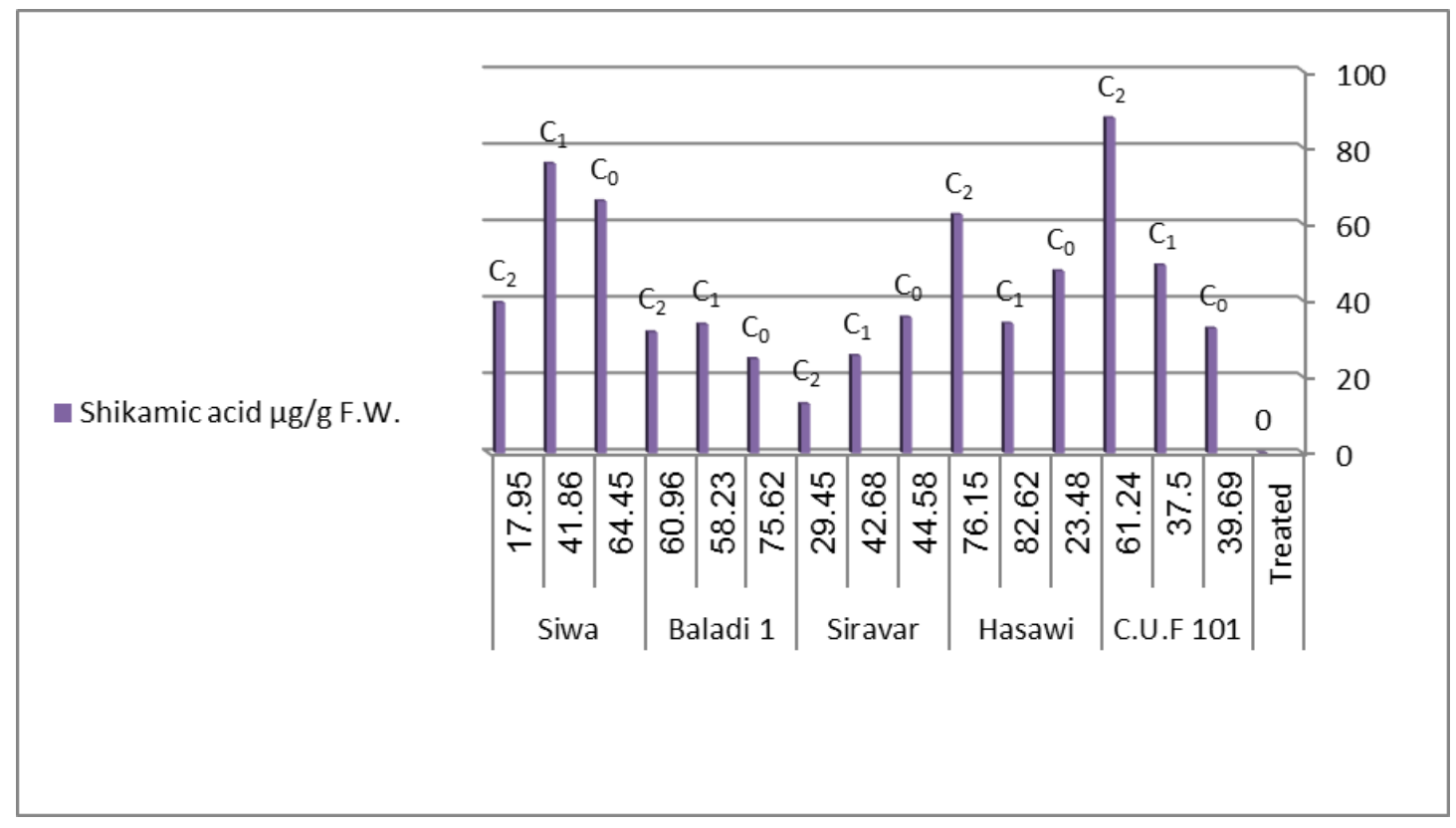

Fig. 3: The interaction between alfalfa populations and selection cycles reflected on values of shikamic acid.

The value of injury level decreased in both of Siwa and Hasawi populations after the first cycle of selection to glyphosate tolerance $(-19.51$ and $13.22 \%$, respectively). Whereas, in the rest of studied populations, an increase in values of injury level increased after one cycle of selection $(+35.00$, +29.41 and $+24.38 \%$ percent for Baldi1, Sirivar and C.U.F101 populations, respectively,). Meanwhile, the progress of selection for glyphosate tolerance in alfalfa populations, gave a substantial decrease in value of injury level in all studied populations, except for, Siwa population that recorded an increase in value of injury level $(-47.05,-44.44$, 40.91 and -4.35 percent of the respective value recorded for injury level at the first cycle of selection in C.U.F101, Baladi 1, Sirivar and Hasawi populations, respectively). These results match true with the findings recorded by Zobiole et. al 2010 , whose found that, nutrient accumulation and photosynthesis in glyphosate resistant soybeans was reduced under glyphosate use. They added that, the chlorotic symptoms might be related to decreased photosynthetic rates as a result of direct damage of glyphosate to chlorophyll and immobilization of $\mathrm{Mg}$ and $\mathrm{Mn}$ (due to glyphosate action to nutrient complexes) required for chlorophyll formation and photosynthesis, respectively.

Concerning shikimic acid content,in all populations, change in shikimic acid content represented bya decrease reached $-35.05,-22.99$, 5.49 and $-4.26 \%$ in Siwa, Baldi 1, C.U.F 101 and Sirivar populations, respectively, after the first cycle of selection for glyphosate tolerance. Only Hasawi population recorded an increase in shikimic acid content reached $+251.8 \%$ relative to base population. While, after the second cycle of selection an increase in shikimic acid content reached +63.60 and $+4.688 \%$ for C.U.F101 and Baldil populations relative to $\left(\mathrm{C}_{1}\right)$. On the other hand, Siwa, Sirivar and Hasawi populations recorded a decrease in shikimic acid content reached $-57.11,-30.99$ and -7.83 respectively relative to $C_{1}$. These results agree with the findings recorded byAmrheinet al. 1980, who studied the mode of action of the herbicide glyphosate. They found that, glyphosate inhibits the enzyme 5enolpyruvylshikimate-3-phosphate (EPSP) synthase in the shikimic acid pathway. Kim and Amrhein, 1995, studied long term analysis of a shikimic acid accumulation and chlorophyll degradation in Tomato plant .They found that, glyphosate induced the rapid accumulation of shikimic acid within 24 hours (h). The accumulation of shikimic acid companied with chlorophyll loss in meristematic leaves, i.e.; apical leaves. The chlorosis was acropetal in apical region of young growing leaf. The degradation of chlorophyll seems to be a secondary or tertiary effect of glyphosate. Zelaya and Micheal(2002) carried-out aspectrophotometric methods based on the oxidation of shikimic acid with periodate to form trans-2-pentene-1,5,dialdehyde-3-carboxylic acid, followed by alkalinization and optical density (OD) detection at 380 nano meter(nm). Visual herbicide injury was 
apparent at 72 hours after treatment (HAT) and near plant death occurred at 192 HAT for either susceptible crop variety. The pattern of shikimic acid accumulation was consistent with the principle that, glyphosate inhibits EPSPS. Susceptible plants accumulated more of the unphosphorylated substrate of EPSPS than resistant plants. Pline-Srnic (2006) studied physiological mechanisms of glyphosate resistance. He said that, the use of at least three different mechanisms has conferred glyphosate resistance in normally sensitive crop species. Early work focused on progressive adaptation of cultured plant cells to stepwise increases in glyphosate concentrations. The resulting cells were resistant to Glyphosate because of EPSPS over expression, EPSPS gene amplification, or increased enzyme stability. Further work aimed to achieve resistance by transforming plants with glyphosate metabolism genes. An enzyme from a soil microorganism, glyphosate oxidoreductase (GOX), cleaves the nitrogen-carbon bond in glyphosate yielding aminomethylphosphonic acid. Another metabolism gene, gly-phosate $\mathrm{N}$-acetyl transferase (gat), acetylates and deactivates glyphosate. A third mechanism, and the one found in all currently commercial glyphosate-resistant crops, is the insertion of a glyphosate-resistant form of the EPSPS enzyme. Zelaya and Owen (2014) reported that, species demonstrated an inherent variability to glyphosate. Correlation of tissue shikimic acid and phenotype in the field supported the tenet that, the response was attributable, at least in part, to differences in glyphosate inhibition of 3phosphoshikimate 1-carboxyvinyltransferase (EPSPS; EC 2.5.1.19). Whole plant dose responses of the Everly, Iowa A. tuberculatus and a pristine population from Paint Creek, Ohio, indicated that, the Everly biotype demonstrated more variability to glyphosate than the unselected population. Isolation of resistant and susceptible plants through recurrent selection resulted in a 1.7 and 3.5 fold increase in population divergence in the first $\left(\mathrm{F}_{1}\right)$ and second $\left(\mathrm{F}_{2}\right)$ filial generations, respectively. While the selection method has increased the frequency of resistant individuals within the population, significant segregation for glyphosate efficacy was still apparent in the selected material. This limited segregation suggested that, the response to glyphosate observed in A. tuberculatus may be governed by a polygenic event. Evaluations of mechanisms of resistance through the recurrent selection of $A$. tuberculatus was based on the seedling assay. This approach elucidated resistant and susceptible individuals, however, the method has potential for misidentification of phenotypes. They added that, a three level selection approach will be conducted to isolate plant material suitable for translocation, metabolism, and EPSPS DNA sequence analysis. Plants will be characterized by their response to glyphosate at the seedling and whole-plant level and their shikimic acid accumulation patterns. The recent literature clear the possibility of reaching a glyphosate tolerant genotypes depending on variability of ecotypes within population in sensitivity to cide. Those cideinjury escapee, represents the source of genes responsible for tolerance to cide in the following generation. Sharing genes among tolerant individuals, increase the frequency of genes responsible for tolerance, consequently expressing higher levels of cide- tolerance. The recent results assume the possibility of obtaining glyphosate tolerant alfalfa population depending on frequent cycles of recurrent selection.

\section{REFERENCES}

Antonovics, J., and A. D, Bradshaw, 1970. Evolution in closely adjacent plant populations. VIII. Clinal patterns at a mine boundary. Heredity, 25; 349-362.

Antonovics, J., (1971). The effects of a heterogeneous environment on the genetics of natural populations. Amer. Sci., 59; $593-$ 599.

Amrhein N., J. Schab and H.C.Steinrücken. 1980. The mode of action of the herbicide glyphosate. Naturwissenschaften67; 356:357.

Amrhein N., B.Deus, P.Gehrke, HC. Steinrucken. 1980. The Site of the Inhibition of the Shikimate Pathway by Glyphosate. 2. Interference of Glyphosate with Chorismate Formation Invivo and Invitro. Plant Physiology 66; 830-834.

Beversdorf, W.D and L.S.Koh.1987. Development of Triazine resistance in crops by classical plant breeding. Weed Sci., 35; 9-11.

Boerboom C.M, N.J. Ehlke, D.L.Wyse and D.A. Somers. 1991. Recurrent selection for glyphosate tolerance in Birdsfoot Trefoil. Crop sci.31; 1124-1129.

BusiR.and S.B. Powles.2011. Reduced sensitivity to paraquat evolves under selectionwith low glyphosate doses in Lolium rigidum. Agronomy Sust. Develop., 31; 525-531.

Devine.T.E.,R.R.Seaney, D.L.Linscott, R.C.Hagin and N.Brace.1975. Results of breading for tolerance to 2,4-Din birdsfoot trefoil. Crop Sci. 15; 721-724.

Duke,S.O., A. M. Rimando, P.F. Pace, K. N. Reddy and R.J. Smeda.2003. Isoflavin, glyphosate, and aminomethylphosphonic acid levels in seeds of glyphosate- treated, glyphosateresistant soybean. Journal of Agriculture and food chemistry, 51; 340-344.

Duncan,C.N and S.C. Weller. 1987. Heritability of glyphosate susceptibility among biotype of field bind-weed.J.Hered.78; 257-260. 
Gottrup,O., P.AO, Sullivan, R. J. Schraa and W. H. Vanden Born. 1976. Uptake, translocation, metabolism and selectivity of glyphosate in Canada thistle and leafy spurge. Weed Res. 16-197: 201.

Hartwig,E.E. 1987. Identification and utilization of variation in herbicide tolerance in soy bean (Glycine max) breeding. Weed Sci, 35;4-8.

Kim. T. W. and N. Amrhein.1995. Glyphosate toxicity: 1. Long term analysis of shikimic acid accumulation and chlorophyll degradation in Tomato plant. Kor. j. weed sci. 15(2);141-147.

Markwell, J., J. C. Osterman, and J. L. Mitchell. 1995. Calibration of the Minolta SPAD-502 chlorophyll meter. Photosynth.Res. 46; 467472.

Muooz-Rueda A., C. Gonzalez-Murua, J. M. BecerrilandM.F. Slnchez-Deaz 1986. Effects of glyphosate [N-(phosphonomethyl)glycine] on photosynthetic pigments,stomatal response and photosynthetic electron transport in Medicago sativa and Trifolium pretense. Physiol. Plant. 66; 63-68.

Neal, J. C, W. A. Skrock and T.J.Monaco.1985. Effect of plant growth stage on glyphosate. Plant phsiol.76; 551-574.

Owen M.C, M.J Walsh, R.S Llewellyn and S.B. Powles. 2007. Widespread evolution of multiple herbicide resistance in annual ryegrass (Loliumrigidum) populations within theWesternAustralianwheat belt.Aust J Agric Res, 58; 711-718.

Pline-SrnicW .(2006). Physiological mechanisms of glyphosate resistance. Weed Technology, 20(2); 290-300.
Reddy, K.N and R.M. Zablotowicz.2003. Glyphosate-resistant soybean response tovarious salts of glyphosate and glyphosate accumulation in soybean nodules. Weed Sci. 51; 496-502.

Shah, D. M., R.B. Horsch, H.J.Klee, G.M.Kishore, J.A.Winter, N.E.Tumer, G.M.Hironaka, P.R.Sanders, C.S.Gasser, S.Aykent, N.R.Siegel, S.G.Rogers and R.T.Fraley.1986. Engineering herbicide tolerance in transgenic plants. Science (Washington,DC)233;478481.

Zelaya I.A,J. A. H.Anderson, M. D. K.Owen andR. D.Landes. 2011. Evaluation of Spectrophotometric and HPLC Methods for Shikimic Acid Determination in Plants: Models in Glyphosate-Resistant andSusceptible Crops. J. Agric. Food Chem. 59 (6); 2202-2212.

ZelayaI.A andM.D.K. Owen 2002. Evaluation of spectrophotometric methods for shikimic acid determination in plants. North Central Weed Science Society Abstracts 57; 39.

Zelaya I. A. and M.D.K.Owen. 2014. Herbicideresistant crops and weed resistanceto herbicides. Pest Management Acience 61(3); 301-311.

Zenk, M. H. 1974. Haploids in physiological and biochemical research, in: "Haploids in Higher Plants: Advances and Potentials," K. J. Kasha, ed., Univ. of Guelph, Guelph, Canada.

ZobioleL.H.S, R.S. Oliveira, R.J. Kremer, A.S. Munizand A. Oliveira Jr. 2010. Nutrientaccumulation and photosynthesis in glyphosate resistant soybeans is reducedunder glyphosate use, J. Plant. Nutr. 33; $1860-1873$. 


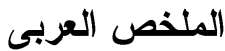

\section{دلائل الضرر عند معاملة البرسيم الحجازي بمبيد الجليفوسات وتأثرها بالاتخاب الدوري محمد عبد الستار أحمد، أحلام حسني محمد، سناء إبراهيم ميلاد، طه أحمد محمود \\ 'قسم علوم المحاصيل- كلية الزر اعة(الثناطبى)- جامعة الاسكندرية

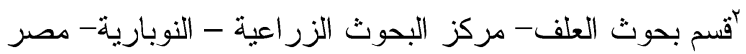

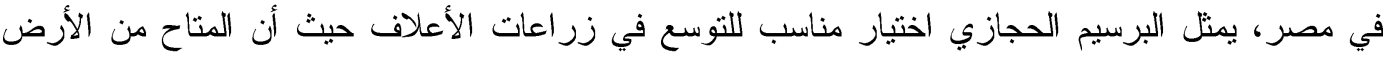

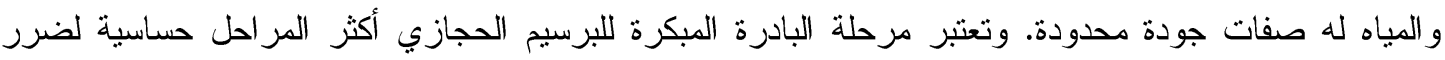

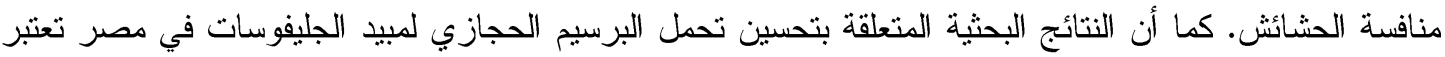

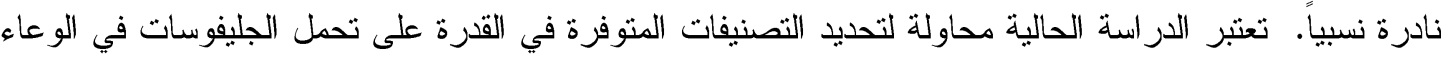

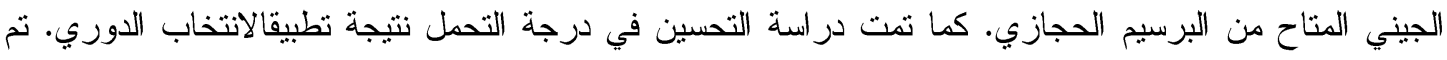

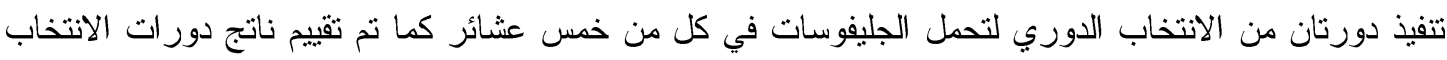

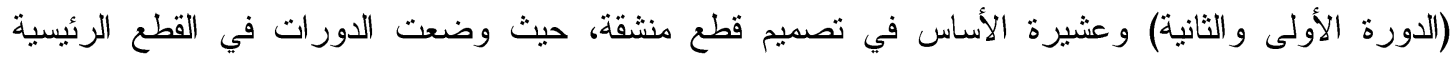
ووضعت المعاملة وعدم المعاملة بالجليفوسات(+و و -) في القطع الفرعية. نم تقييم القطع الحقلية المعاملة بالجليفوسات

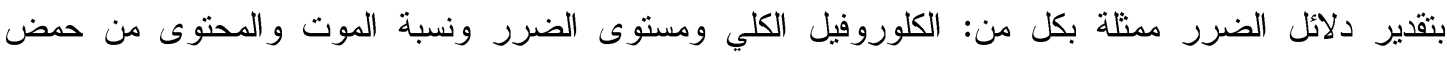
الثيكمك. سجلت اختلافات معنوية بين عثائر البرسيم الحجازي المدروسة. كماختلفت القيم المسجلة بجميع دلائل الضرر المدروس بين دورات الانتخاب و العشائر المدروسة في نفس الوقت، كان التفاعل بين العشائر ودورات

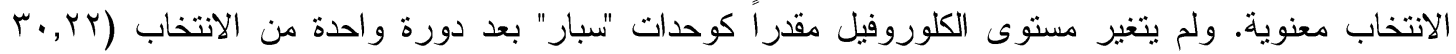

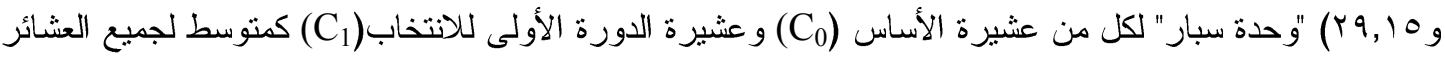

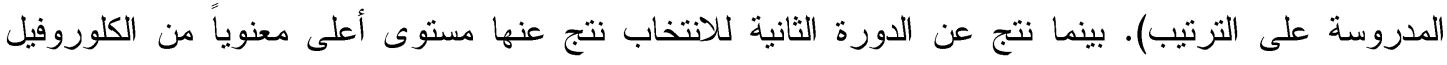

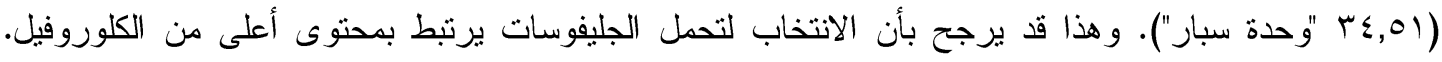

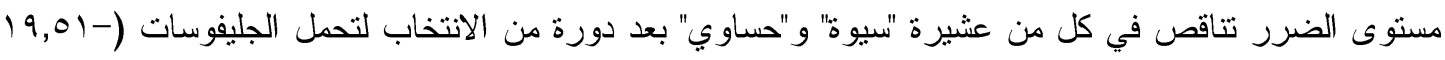

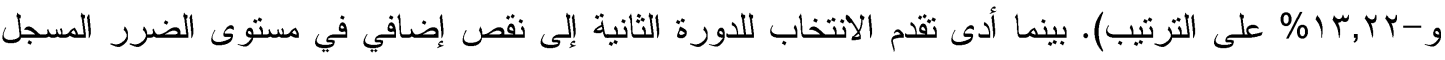

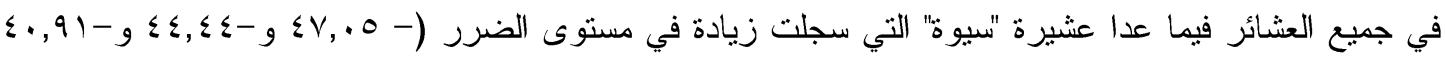

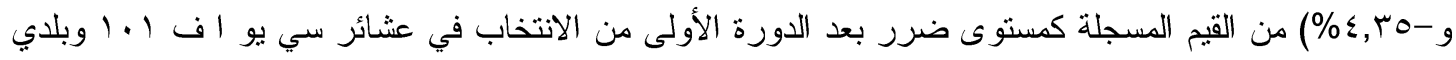

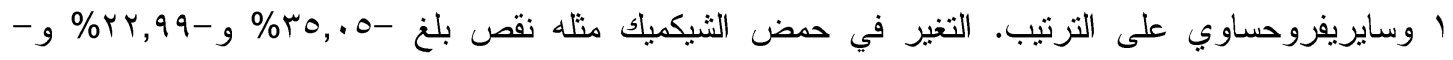

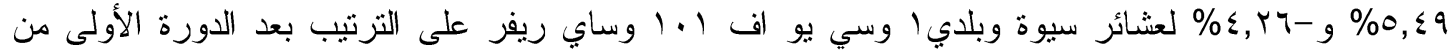

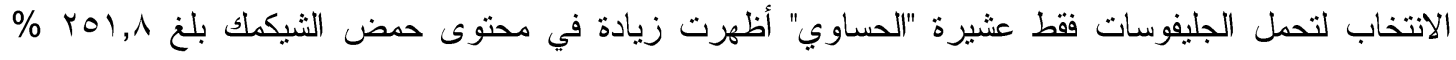
بالنسبة لعشيرة الأساس. بينما حدثت زيادة في محتوى النباتات من حمض الثيكميك بعد الدورة الثانية من الانتخاب

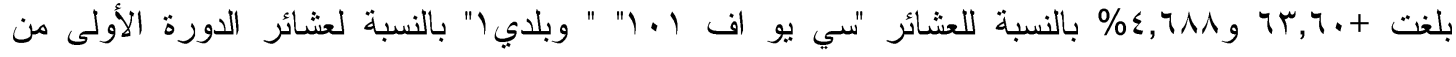
الانتخاب(C) مستويات أعلى من تحمل المبيد وتوضح الدراسة الحالية إمكانية إنتاج عشيرة برسيم حجازي متحملة للجليفوسات اعتمادا على تكر ار دورات الانتخاب. 